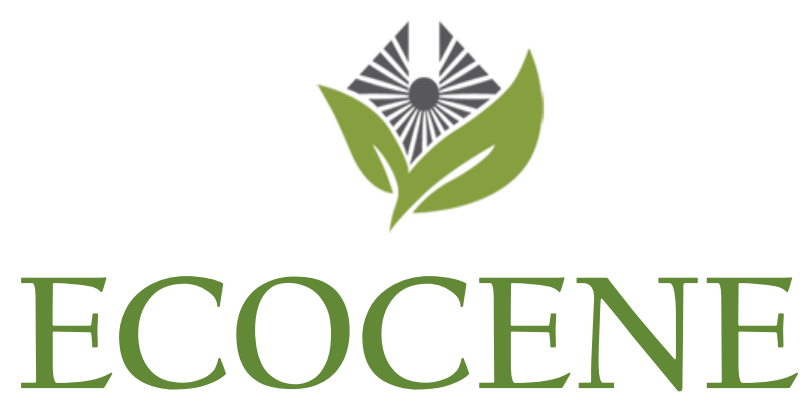

CAPPADOCIA JOURNAL OF ENVIRONMENTAL HUMANITIES

Volume 1/ Issue 1/June 2020

Environmental Humanists Respond to the World Scientists' Warning to Humanity

\title{
A Sea Change in the Environmental Humanities
}

\author{
Cecilia Åsberg \\ KTH Royal Institute of Technology, Sweden \\ Linköping University, Sweden \\ cecilia.asberg@abe.kth.se \\ ORCID: 0000-0001-7794-3806
}

Åsberg, Cecilia. 2020. “A Sea Change in the Environmental Humanities.” Ecocene: Cappadocia Journal of Environmental Humanities 1, no. 1 (June): 108-22. https://doi.org/10.46863/ecocene.2020.12.

Research Article/ Received: 03.07.2020 /Accepted: 15.06.2020

This work is licensed under a Creative Commons Attribution 4.0 International License.

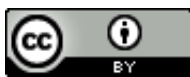




\section{A Sea Change in the Environmental Humanities by Cecilia Åsberg}

Abstract

As we are living through a transformative response to a viral pandemic, this think piece suggests a reimagining of the environmental humanities in the open-ended inventories of feminist posthumanities and the low trophic registers of the oceanic. Sea farming of low trophic species such as seaweeds and bivalves is still underexplored option for the mitigation of climate change and diminishing species diversity in the warming oceans of the world. The affordances of low trophic mariculture for coastal life and for contributing to society's transition into climate aware practices of eating, socializing and thinking is here considered, and showcased as an example of the practical uses of feminist environmental posthumanities.

Keywords: feminist environmental humanities, feminist posthumanities, oceanic studies, low trophic theory

About the Author

Cecilia Åsberg is guest professor at KTH Royal Institute of Technology in Stockholm, and professor of Gender, nature, culture at Linköping University, Sweden. 


\title{
A Sea Change in the Environmental Humanities
}

\author{
Cecilia Åsberg
}

In this moment, due to a virus, we are living through a transformative response that exhibits how things very swiftly could be done very differently. In this particular pandemic practice, the doing of a political ecology, there are a million threats to lives and to democracy at large, but also grains of hope, and agency. Succinctly, Arundhati Roy (2020) describes the pandemic as a portal, a gateway to an involuntary re-visioning of the world we inhabit:

\begin{abstract}
Whatever it is, coronavirus has made the mighty kneel and brought the world to a halt like nothing else could. Our minds are still racing back and forth, longing for a return to "normality," trying to stitch our future to our past and refusing to acknowledge the rupture. But the rupture exists. And in the midst of this terrible despair, it offers us a chance to rethink the doomsday machine we have built for ourselves. Nothing could be worse than a return to normality. Historically, pandemics have forced humans to break with the past and imagine their world anew. This one is no different. It is a portal, a gateway between one world and the next. We can choose to walk through it, dragging the carcasses of our prejudice and hatred, our avarice, our data banks and dead ideas, our dead rivers and smoky skies behind us. Or we can walk through lightly, with little luggage, ready to imagine another world. And ready to fight for it.
\end{abstract}

At times of great emergency and fast action, as in the present situation, we need slow, uneasy theory alongside pointed knowledge practices for the transformations that transport us outside our comfort zones. If this outbreak, like others before it, can be traced back to our cruel treatment and confinement of nonhuman animals, such as those at Chinese wet markets or Swedish chicken farms (examples abound everywhere in the world), let us now abandon it! As Roy (2020) stated: Nothing could be worse than a return to normality. What we need is more knowledge (a light burden) and pointed practice on those, still largely unfamiliar, nonhuman powers, and how they 
process the world with us in it. Such insights need to pervade also the environmental humanities (EH). In fact, this changes everything for the environmental humanities. And yet, taking on board more-than-human and nonhuman forces does not throw overboard analytics of human power differences such as feminist, eco-critical, or decolonial thought. Quite the contrary; it hones those skills of understanding environed embodiment/embodied environment and mitigating the politics of exclusion, inclusion and always asks "cui bono" (who benefits)? So this cannot be the kind of territorial environmental humanities that drags the carcasses of disciplinarity, of prejudice, even hate, and dead ideas behind us. This new post-epidemic environmental humanities needs open-ended, bio-curious, and critical practices of thinking and doing things together across modern divides of nature and culture, disciplines, universities, academic and everyday life, and across national boundaries. It needs insights from medical humanities, technohumanities, biohumanities, chemical humanities, and other fields to stay societally relevant. Knowledge is always a light burden, variously situated and available to the reimagining of the world that now must ensue in the light of climate change and mass species extinction, political polarization, and global pandemics.

In this essay I want to address not just the importance of reckoning with the nonhuman in environmental humanities, but in particular with the oceanic forces of nonhumanness that we (unknowingly) live, breath, eat, socialize, and die by. Specifically, I wish to highlight the ways in which feminist and situated practices of posthumanities has the potential to productively mitigate shortcomings inherent in the disciplinary practices that make up the diversity we have come to term environmental humanities. While alarmist notions of climate change, environmental deterioration, and diminishing species diversity fulfil an important function (they instigate needed social change), they often also underscore a common modern environmental discourse on (generic) Humans versus (reified) Nature assisted by (monolithic) Science. This is problematic and needs to change in the environmentalist discourse. In the words of Jonathan Safran Foer (2019), we are the weather. We are the climate and the climate is us; we are in the environment just as the environment is in us (Åsberg 2013). If environmental humanities is going to maintain its relevance in a world changed by nonhuman powers, such as viruses or oceans, this needs to sink in by now. Feminist posthumanities, as proposed here, takes this integrative approach to human and nature, and to science and art within environmental humanities research. It includes medical/ technical/chemical/biological or multispecies humanities, and their roots in the grounded empirics and decolonizing theory of feminist science and technology studies, in order to stay as adaptive to change as the world it attends to. I want in this short piece to showcase and exhibit the potentials of a minor case of such posthumanities in 
practice by attending to ongoing work, in the interstice of art and science, in low trophic sea culture. In the process, I hope to draw attention to the sustainability potentials of such concrete and situated posthumanities practices and to the many promises of the overlapping environmental humanities subfields of oceanic studies and blue humanities (DeLoughrey 2017; Alaimo 2012, 2019). In fact, I hope to show that such approaches (as to be found, or developed, in feminist posthumanities) are key to a reinvigoration of environmental humanities at least. In any case, it is a suggestion for trails ahead. It is my 50 cents at travelling light (but knowledge-intensively) through the portal to a post-pandemic environmental humanities of greater scope. With the integrative approaches of feminist posthumanities, it is here argued, we find openings for a set of environmental humanities practices that would embrace greater diversity as well as critical and creative approaches to science and to the unknown; to time and the always already postnatural human-nonhuman bundle, and to the diversity of people situated in ecological contexts as well as the diversity of nonhuman forces situated ethically.

\section{Us, the Postnatural Environment: Nonhuman Forces into Environmental}

\section{Humanities}

The environment, a term that dates back only 60 years, has been defined by biophysical indicators and researched through evidence-based natural science. Common understandings of the environment today, as a passive background, original and pure source or even playground for sporty men, find their way into environmental policy and practices of the environment as a resource to be managed, mastered, and exploited (Plumwood 1993). This modern notion (akin to "nature") makes the environment other to culture and positions it as a repository for human nostalgia, fear, or tranquility (Neimanis, Åsberg, and Hedrén 2015). It is often evident in well-intended, rallying scientists' Cassandra-cries for politicians and citizens to change their environmental directives. Such positioning, making the environment other to everyday life and siloed into expert domains, has resulted in a prolonged nature-culture divide in our institutions and imaginations, causing many in the Global North to feel alienated from ecology and apocalyptic about its environmental future (Neimanis, Åsberg, and Hedrén 2015). It leads to many people considering human matters as entirely divorced from environmental issues, while they in fact are deeply and existentially entangled. For instance, climate change has mostly been represented and understood as a scientific problem in need of technological solutions. However, that situation has been slowly transformed with new research; environmental humanities begins from the position where climate change and environmental degradation are seen as social problems in need of diversified solutions. Science has explained this problem and its impacts, but 
the humanities and the arts are needed to help us understand how to live with, adapt to, and mitigate the social crises and anxieties that are emerging (Neimanis, Åsberg, and Hedrén 2015; Adamson and Davies 2017).

To preach to the choir and reiterate a well-versed story, environmental humanities works for societal transformation from the proposition that we have entered a geological era of humanity's own making that requires attention to accountability, social justice, and equitable sustainability, to ethics, values, and sense-making that expand and foster new environmental sensibilities in people. This would make long traditions of open-ended, indigenous, and feminist theorizing a given component in the mix, but that has not always been the case. Environmental humanities, after almost a decade of increasing global academic recognition, is after all the power-fraught merger of academic humanities and social science studies, disciplines and fields conjoined into a new generation of environmental research that methodologically aims to enliven ecological imaginations, extend reparative possibilities and explore alternative futures (Rose et al. 2012; Åsberg, Hedrén, and Neimanis 2013; Gibson, Rose, and Fincher 2015; Radomska 2018). To address perceptions and knowledge, it often relies on the related insights of cultural and historical Science and Technology Studies (STS) while retaining various degrees of its more disciplinary origins in literary eco-critique, environmental history and philosophy, and in the eco-feminist postdisciplinarity of Australian ecological humanities emerging from philosopher Val Plumwood's collectives. These are fields that pioneered approaches that took the force of nonhumans seriously, for instance in the veins of actor network theory (ANT), Bruno Latour and Donna Haraway. Today, environmental humanities often meets up more generously with diverse forms of new materialist feminist theory for approaching values, aesthetics, materiality, and the nonhuman. However, rising to the entangled challenges of today's situation presented by political polarization as much as global pandemics, synthetic biologies, AI, and other technological advancements, requires an even more integrative approach; an enlivened field of postnatural humanities, so-called posthumanities (Halberstam and Livingston 1995; Wolfe 2003; Åsberg 2008, 2014, 2018). Such multi-targeting "thicker" forms of more-than-human humanities (Rose 2015) bridge the arts and science divide (Åsberg 2018), trace cyborg origins and a billion black Anthropocenes, or none (Yusoff 2019). Driven by feminist epistemologies of societal accountability, situated knowledge (Haraway 1991) and the politics of location (Rich [1984] 1987), such feminist environmental posthumanities adapt to the case at hand the relevant methodologies of the environmental humanities subfields, for instance multispecies studies (Tsing 2015), and oceanic studies or blue humanities (Alaimo 2019; DeLoughrey 2019). 
As I feel strongly that environmental humanities has the opportunity to become even more relevant, more encompassing as well as more demanding in the registers of sustainability science, art, and nonhuman reckonings, especially in the light of the mounting efforts around Agenda 2030 and the up-coming UN-declared "Ocean Decade 2021-2030," I want to dwell in particular on such emerging EH subfields. Oceanic studies, as Elizabeth DeLoughrey calls it, and blue humanities, as Stacy Alaimo calls it, are a rather new branch of environmental humanities and feminist posthumanities, corresponding vigorously to a sea change in the arts and humanities, namely the nonhuman turn (Giffney and Hird 2008). They involve a turn to the political ontologies of the sea, their implications for multispecies temporalities and aesthetics, human communities and more-than-human ethics in the Anthropocene. Influences on the rise of this research are of course the pioneering biomarine writings of Rachel Carson, more famous as the author of Silent Spring (1962), on the ecological effects of pesticides. Yet, its feminist and anti-colonial ambitions are more evident in influences like Paul Gilroy's The Black Atlantic (1993) or Anna Tsing's (2015) and Donna Haraway's (2016) multispecies works. In effect, it draws on a range of geographical, historical, and cultural works for the understanding of the oceans as a force rather than a place to be managed (Oreskes 2014; Povinelli 2014; Helmreich 2008; Steinberg and Peters 2015; DeLoughrey 2017; Neimanis 2017). The oceanic turn I explore here, draws on the appeal of these overlapping oeuvres of environmental humanities and feminist posthumanities, and yet focuses on the oceanic, on slow violence (Nixon 2013), and the less explored affordances of low-trophic thinking with sea ecologies. This demands the aforementioned theoretical grounding in environmental humanities and feminist posthumanities in its science-and-society oriented and more-than-human registers. Forged in this previous research, our new research with The Posthumanities Hub (my research team) explores environmental violence and postnatural care in the interstices of art and science, ocean and land, theory and public appeal. Allow me to try to fathom the relevance of the oceanic turn and what I have come to call low-trophic theory.

\section{Sea Changes to Our Climes}

It is well known that to heed the climatic warnings of environmental scientists, reduction and halting of carbon dioxide emissions are key to climate change mitigations. Systematic changes are needed (Ripple et al. 2017). From the two latest Intergovernmental Panel on Climate Change (IPCC) reports we also know that there is a devastating difference in future earth scenarios between the goals of 1.5 degree Celsius and 2 degrees. Yet, the initial plummeting of emissions reported from pandemic-seized China in February by an improbable 25 percent translated in early April into a more 
modest 5.5 percent reduction (compared to 2019, the year before) in greenhouse gases world-wide. Fair enough. As many left the car to huddle at home and industries came to a grinding halt, emissions went down. But not good enough as the climate situation is a highly complex organism on this planet. Economic recessions in the very near past have reduced $\mathrm{CO}_{2}$ emissions before, and then bounced right back with a vengeance as the global economies recuperated. There are, however, many reasons to celebrate the cleaner air, especially in these corona times. At this moment, most urbanites enjoy a far better air quality-which medical science links to better health chances in patients with COVID-19 (as it affects the lungs too). Enhanced air quality links also to lower mortality at large, since fine air particulates in smog, vehicle emissions, and air pollution annually kill people at the rate of the Novel coronavirus (nCoV) but with less notoriety. Every year.

Simply put, public health improves with better air. In the midst of this pulmonaryassociated COVID-19 pandemic, this is fortunate (Neira and Ramanathan 2020; Gerretsen 2020). On the other hand, and oddly enough, our warming planet was also partially shielded from the warming rays of the sun, because these were deflected in clouds seeded with densifying pollutants such as sulphate aerosols. It has been suggested that industrial air pollution actually offsets a third of the greenhouse warming, while adding to it - and to other environmental problems such as acid rainin the long term. In the short term, however, a drop-off in atmospheric pollutants can actually cause a slight and sudden increase in global warming, which is now contemplated by climate researchers in relation to the Arctic heatwave and the melting of permafrost in the summer of 2020 (Diamond et al. 2020). One particularly efficient source of cloud pollution is the super-dirty fueled cargo ships that cross the oceans. And oceans, with their extremely wide surfaces that cover 71 percent of the planet, are more susceptible to and absorbent of warming than land. The deep seas and oceans, of which a majority (64 percent) is beyond national jurisdiction, absorbs in fact vast amounts of heat and carbon dioxide (Levin and LeBris 2015). Our seas and deep oceans really do constitute a critical buffer to climate change in both a metaphorical sense (Oppermann 2019) and a lived (or dying) sense of exposing vulnerable ecosystems to the combining stressors of warming, ocean acidification, and deoxygenation. Resulting changes loom large over biodiversity, human livelihoods included. In truth, oceanic changes have been dramatic of late, including the warming of waters and ocean acidification, deoxygenation, species migrations, and habitat loss. So let us turn our climatic sensibilities to the edge of the sea for a while.

All through the extended history of Earth, the coast line has been a zone of unrest where waves and tides have forged life and land on this planet. Oceanic algae, once 
terraforming Earth into a breathable planet, still produces most of our oxygen. The deep sea is not our given element while anthropogenic forces have been invasive here too, searching for minerals, oil and gas, and leaving a trail of pipelines and litter behind. Yet, the edge of the sea remains a strange and beautiful place, as Rachel Carson remarked in The Edge of the Sea ([1955] 1998), with all its wondrous creatures in mind. Low-trophic marine zones, with kelp and other macro-algae (seaweeds), oysters, mussels and sea urchins, provide a host of benefits to various organisms, humans included, in providing many species with sanctuary and mitigating the eutrophication of the sea. Comparing this zone to the forests, Charles Darwin (1839) already observed the sheer "number of living creatures of all Orders whose existence intimately depends on kelp," and warned of the insurmountable effects should it perish (Filbee-Dexter, Feehan, and Scheibling 2016; Filbee-Dexter and Wernberg 2018). Today, kelp forests and mussel beds are receding with the warming waters of climate change. They seem to in fact slowly perish however nutritious and beneficial they are for many species, including humans (Aksnes et al. 2017). In dire times of environmental degradation, ocean acidification, and climate change, it is about time we turn our attention and appreciation to such low-trophic creatures, to the habitat of the tidal zone, and to mariculture, as in a partly submerged environmental arts and humanities project, "Sea Change/Sea Edge," which we are developing within this Swedish-international research group.

"Sea Change/Sea Edge" is a postdisciplinary knowledge and capacity-building project on the potential of coastal mariculture (aquaculture in marine environments) aiming to connect marine sciences, natural history, cultural heritage, and sustainability engineering with arts and feminist environmental humanities research. The overall goal is to deepen ecological understanding and culturally contextualize scientific insight in eco-feminist theory, posthumanities, and coastal communities so as to stimulate society's cultural imagination and invite a sea change of ethical, culinary, and cultural responses to the state of sea life. In order to catalyze such social change, this project examines and aims to unlock the transformational potential of eating, socializing, and thinking with low tropic sea life and with mariculture initiatives. The research is conducted by environmental humanities scholars (feminist posthumanities, science studies, and eco- and bio-art philosophy), sustainability scientists, seaweed farmers, and EHoriented artistic researchers like the artistic duo "Cooking Sections" (based in London). One of the outcomes of this research is to be a large art exhibition entitled ClimavoreHow to Eat as Humans Change Climate with Bonniers Konsthall in Stockholm in 2021. But it is still very early days in this research. So far we only know what we can read from the annals of the marine sciences, and from what we have learned in artistic workshops on 
kelp foraging, kelp curing, kelp cooking, and kelp curating (Åsberg, Holmstedt, and Radomska, forthcoming).

\section{Sea Farming and Practicing Low-trophic Feminist Posthumanities between Art and Science}

The role of marine and coastal aquaculture (mariculture) - to provide delicious food and carbon neutral materials from the sea for society without adding to land-based stresses-is on the rise for the mitigation of climate change and diminishing species diversity. Science exhibits how low-trophic marine aquaculture of non-fed and nonfertilized species, such as sea weeds (like sugar kelp or more commonly known edible seaweeds such as nori or dulce), oysters, mussels, tunicates, and sea squirts, shows substantial potential in contributing to sustainable development. Acting as environmental engineers in their own right, these creatures actually capture and sink $\mathrm{CO}_{2}$, while they nourish and provide habitat for a range of penchant species. They thus mitigate some of the worst threats to the oceanic life on this planet without the need for chemicals or man-made fodder, and they can be cultivated by laypeople very easily or can just be harvested directly in shallow waters. Freely available by the shore or cultivated in small-scale sea allotments (as we envision it, with tourists or locals) or professional seaweed farms (small scale), they provide beach strollers with nutritious food and exquisite umami flavors worthy of top-notch cuisine. And with food for thought. From the viewpoint of sustainability science there is an urgent need to find new ways of producing nutritious food and biomass, to provide food for growing populations with a minimal environmental footprint (Alexandratos and Bruinsma 2012). Land, soils, and fresh water resources are already hard-pressed by agriculture. One pathway to reducing pressures on land involves looking to our oceans for answers. After all, the oceans are already central to human well-being, and they provide, in the vernacular of science, vital "ecosystem services" such as climate regulation, food, energy, mineral, and genetic resources. Salmon farming, a form of aquaculture that entails raising a specific strain of Atlantic salmon "from egg to market" and keeping the fish in net cages in marine settings, e.g., along Norwegian, Irish, and Scottish coasts, is in fact also the fastest growing food production system in the world. Yet it might be marine aquaculture at its worst. While capture-fishery landings have been stagnant since the 1990s and while wild populations of finfish have been dwindling at record speed to the detriment of human livelihoods, the increasing demand for seafood has been met by intensified aquaculture, especially salmon farming.

A postnatural species par excellence, farmed salmon hosts an array of negative impacts on the ocean and contributes to environmental violence at both slow and fast 
paces. It adds to eutrophication and biodiversity loss as the chemicals, antibiotics, and excess nutrients from food and feces from the over-crowded net cages disturb the oceanic flora and fauna directly under and around the sea farms. In fact, the excessive use of chemicals, including anti-foulants and pesticides (banned in some countries, though water is fluid and trans-governmental), are still to have unintended consequences for marine organisms and human health for futures to come. Parasites like salmon lice and viruses transfer easily inside the pen and between farmed and wild populations. And when they escape from their heavily regulated regime (it happens), the often weirdly disoriented designer salmon interbreed with wild populations to alter and diminish genetic diversity (Schiermeier 2003).

The bio-designed Atlantic salmon, a species genetically bred from a few Norwegian strains for faster growth and economic gain (Schiermeier 2003), have taken center stage but need to be dethroned. Like flamingos turning pink, the iconic salmon pink hues come from wild salmon eating shrimp and krill and ingesting the coloring compound astaxanthin. Farm-raised salmon, however, would have a naturally grey-colored flesh were it not for their chemically engineered feed, adding the pink color to custom-made and desired degree.

We work for this project with the artistic duo Cooking Sections. Informed by their previous project on salmon as a color oddity, generated by the metabolization of manmade substances in nonhuman bodies, this salmon describes "the color of wild fish which is neither wild, nor fish, nor even salmon" (Tate Britain: Art Now: "Salmon - A Red Herring" by Cooking Sections). Such anthropogenic fouling of the oceans by way of salmon needs to be replaced. With Cooking Sections and with sustainability scientists at KTH qua sea farmers, we propose sustainable alternatives in practices of eating, socializing, and "thinking with" low-trophic species around the local coastlines of Sweden.

In essence, fish farming has so far been unsustainably cultivating high-trophic marine species that are equivalent to lions, leopards, and wolves-top predators of their ecosystems-which implies significant energy inefficiencies and a far greater environmental footprint than is needed from a nutrition perspective. In addition, such salmon farming depends on chemicals, entails the suffering of fish, and contributes greatly to eutrophication and toxic pollution. Kelps and other sea weeds work the other way around, whether we cultivate them or not, and they lend themselves to new, more sustainable ways of eating, socializing, and thinking by the sea for people. Or so we suspect, as we hope to get to test these practices (in philosophical cooking workshops and sea weed mini-allotments) amongst local fishing and tourist villages in the years to come. 


\title{
Food for Thought: Low-trophic Field Philosophy
}

Low-trophic theory in feminist posthumanities (Åsberg, Holmstedt, and Radomska, forthcoming) is all about learning to eat, socialize and think with ecological niches that support life on earth. To a large degree it is about resisting human supremacy and its twin dynamics of sacralizing or cannibalizing (Bryld and Lykke 2000) in the oceanic environment, but also about finding a livable, breathable, and tasteful path of practice in the mess of things, as humans change climate. It is also about ending the fatalist practice of separating people from planet, humans from environment, and recognizing new dimensions of multispecies connectivity and temporality, much in the vein of Deborah Bird Rose (2012):

\begin{abstract}
Lives are nourished by others .... All living things owe their lives not only to their forebears but also to all the other others that have nourished them again and again, that nourish each living creature during the duration of its life. Metabolic processes require energy to flow across species and systems; embodied time is always a multispecies project. It follows that life depends both on the sequential processes of generational time/gift and on the synchronous processes of multispecies nourishment. These processes and patterns intersect to form dense knots of embodied time. (130-31)
\end{abstract}

Rose instils an ethical obligation to the multispecies communities with whom we share the sea. This obligation exists not because the death of other species could signal, like the archetypal canary in the coal mine, our own collective death as Homo sapiens, but because we share responsibility for all the bodies, stories, and temporalities we inhabit and consume.

The term "trophic" stems from the Greek term trophē, meaning "nourishment, food." In the context of ecology, the notion of "trophic level" describes the group of organisms occupying the same level in a food chain, meaning, having the same "distance" in relation to the primary energy source (mostly the Sun). What this ecological classification brings to the fore is the very question of nourishment and consumption, which all the living depend on and which there is no way around. It is, after all, the matter of consumption that saturates anthropogenic violence to our planet: the consumption of other creatures, of biomass, of space and potential futures. Yet, in the context of human cultures, consumption-in both its narrow sense of food and broader understanding of consuming the world in its every aspect-is not only about nourishment and material survival. It also amplifies and is amplified by one's identity, belonging, culture, belief, and habit, among others. Furthermore, none of these factors 
remains fixed, immutable, independent of its surroundings, or innocent, for that matter. We do not live in a vacuum. Traditions or habits, even if cherished and preserved, are always performed and entangled in the social, cultural, economic, and ethico-political conditions of a given time and place. Some of these factors are challenged every day in a world where, as consumers, by way of making choice, we also choose to remain complicit, or to resist the structures of environmental violence and injustice. Those choices are not only about the food we eat, its cost in terms of both the carbon footprint and the suffering it may have caused, but also every product or service we decide to buy, out of need or habit, as well as knowledges and stories we prefer to recognize, nourish ourselves with, digest, and consume. Low-trophic in-field philosophy in practice, as we envision it, comes with a realization of our own embeddedness in a trophic system, in an ecological deep time context. And it situates nonhuman creatures in an ethical and contemporary context, in a political ecology as well: hence low trophic theory is about showcasing that "nothing comes without its world," as Maria Puig de la Bellacasa (2012) put it. There is no "outside" or "elsewhere:" we are all differentially situated and differentially responsible inhabitants of this planet, and the question is rather "how can we imagine this world (from within) otherwise?" Inside, and with no exit from "field work" ever possible, how can we inhabit our earthly companionship with less of that slow violence hinged on human ignorance and supremacy within the Environmental Humanities? It is about recognizing existing trophic differences, yet somewhat levelling the playing field for multispecies flourishing. Coastal villages, in this case, may gain value by a (re)development of maritime enterprise, and participants can learn how to eat well as humans change climate and sit out pandemics. What is needed is also a cultivation of the sense of wonder and ecological belonging, the merits of seaside dwelling to mental well-being, and a deeper understanding of how the development of sustainable low-trophic mariculture may influence our common future and interact with society. Early research in Cultural Studies taught us to pay attention to the mundane matters of life, to look at them with curiosity, and see everyday life, popular culture, and consumption patterns not as unworthy low culture, but as the very essence of how we become who we are. If we now see multispecies studies and feminist posthumanities as forms of cultural studies in the nonhuman turn, we may also consider low-trophic mariculture as sustainability practices of eating, socializing, and thinking better together through an ethics of cohabitation and mutual flourishing. Thus understood, low-trophic mariculture points us in a direction beyond the "twin spectres of sacralizing and cannibalizing" (Bryld and Lykke 2000, 203) nature and its resources (of which we are part); it seeks to conceive consumption in the (less anthropocentric) sustainable registers of multispecies flourishing and in an accountable response to 
environmental change, exploring how to flexibly adapt to climatic seasons and polluted periods of land and oceans.

Looking closer at the entangled ecologies of low-trophic ecosystems of seaweeds, oysters, sea urchins, and other creatures reconnects us also with humble origins in deep time settings without a detour to a mythic paradise (lost). And, in the process, they may help us reimagine the uses of theory (Giraud 2019) for the transformative practices of environmental humanities, across trophic levels also in science, art, and society. Drawing on feminist theory and science studies, this is where all diverse and variously situated forms of environmental humanities and arts come in, and make invaluable contributions to the climate warnings the scientific community is addressing to society. First, these contributions make our climatic imaginary more agile and wider in scope. Such research enables us to grasp the uncertainty of scientific predictions without a recourse to epistemic relativism or value nihilism. Second, such inter- or even postdisciplinary environmental humanities enable us to see ourselves as existentially part of the world we want to care for-not as generic Humans pitted against a passive Nature, but as differently situated and politically positioned human and nonhuman actors. We are all environed, embodied and embedded in complex ways on a rare planet travelling across time and space.

\section{References}

Adamson, Joni, and Michael Davis, eds. 2017. Humanities for the Environment: Integrating Knowledge, Forging New Constellations of Practice. London and New York: Routledge.

Aksnes, Dag L., Poul Holm, Maarten Bavinck, Frank Biermann, Roberto Danovaro, Patricia Harvey, and Gesche Krause. 2017. "Food from the Oceans-How Can More Food and Biomass Be Obtained from the Oceans in A Way That Does Not Deprive Future Generations of Their Benefits?" SAPEA Evidence Review Report No.l Berlin: SAPEA. http://doi.org/10.26356/foodfromtheoceans.

Alaimo, Stacy. 2012. "States of Suspension: Trans-Corporeality at Sea." Interdisciplinary Studies in Literature and Environment 19, no. 3 (Summer): 476-93.

Alaimo, Stacy. 2019. "Science Studies and the Blue Humanities." Configurations 27, no. 4 (Fall): 429-32. https://doi.org/10.1353/con.2019.0028.

Alexandratos, Nikos, and Jelle Bruinsma. 2012. "World Agriculture towards 2030/2050: the 2012 Revision." ESA Working paper No. 12-03. Rome, FAO.

Åsberg, Cecilia. 2008. "A Feminist Companion to Posthumanities." NORA: Nordic Journal of Feminist and Gender Research 16(4): 264-69.

_- _ 2018. "Feminist Posthumanities in the Anthropocene: Forays into the Postnatural." Journal of Posthuman Studies: Philosophy, Technology, Media l (2): 185-204.

—— - 2014. "Imagining Posthumanities, Enlivening Feminisms." In The Subject of Rosi Braidotti: Politics and Concepts, edited by Bolette Blaagaard and Iris van der Tuin, 56-64. London: Bloomsbury Academic. 
Åsberg, Cecilia, Janna Holmstedt, and Marietta Radomska. Forthcoming. "Methodologies of Kelp: Transversal Knowledge Production and Multispecies Ethics in an Age of Entanglement." In the Kelp Congress, edited by Neal Cahoon, Hilde Methi, and Annette Wolfsberger. Svolvær: The North Norwegian Art Centre.

Åsberg, Cecilia, Johan Hedrén, and Astrida Neimanis. 2013. The Seed Box: An Application to MISTRA-Formas, the Swedish Research Funding Bodies.

Bryld, Mette, and Nina Lykke. 2000. Cosmodolphins: Feminist Cultural Studies of Technology, Animals and the Sacred. New York: Zen Books.

Carson, Rachel. 1962. Silent Spring. Greenwich: Fawcett Publications.

(1955) 1998. The Edge of the Sea. First Mariner Books Edition, New York.

Darwin, Charles. 1839. Narrative of the Surveying Voyages of His Majesty's Ships Adventure and Beagle, Between the Years 1826 and 1836: Describing Their Examination of the Southern Shores of South America, and the Beagle's Circumnavigation of the Globe. London: Henry Colburn.

de la Bellacasa, Maria P. 2012. "Nothing Comes without Its World': Thinking with Care." The Sociological Review 60 (2): 197-216. https://doi.org/10.11l1/j.1467-954X.2012.02070.x.

DeLoughrey, Elizabeth. 2019. "Toward a Critical Ocean Studies for the Anthropocene." English Language Notes 57 (1): 21-36. https://doi.org/10.1215/00138282-7309655.

_- 2017. "Submarine Futures of the Anthropocene." Comparative Literature Journal 69 (1): 3244.

Diamond, Michael S., Hannah M. Director, Ryan Eastman, Anna Possner, and Robert Wood. 2020. "Substantial Cloud Brightening from Shipping in Subtropical Low Clouds." AGU Advances 1 (March): e2019AV000111. https://doi.org/10.1029/2019AV000111.

Filbee-Dexter, Karen, Colette J. Feehan, and Robert E. Scheibling. 2016. "Large-scale Degradation of a Kelp Ecosystem in an Ocean Warming Hotspot." Marine Ecology Progress Series 543: 141-52. https://doi.org/10.3354/mepsll554.

Filbee-Dexter, Karen, and Thomas Wernberg. 2018. "Rise of Turfs: A New Battlefront for Globally Declining Kelp Forests." BioScience 68 (2): 64-76.

Foer, Jonathan Safran. 2019. We Are the Weather: We Saving the Planet Begins at Breakfast. London: Penguin.

Gerretsen, Isabelle. 2020. "How Air Pollution Exacerbates Covid-19." Future Planet, BBC Future Planet. Accessed 06 March 2020. https://www.bbc.com/future/article/20200427-how-airpollution-exacerbates-covid-19.

Gibson, Katherine, Deborah B. Rose, and Ruth Fincher. 2015. Manifesto for Living in the Anthropocene. Ann Arbor: Punctum.

Giffney, Noreen, and Myra J. Hird, eds. 2008. Queering the Non/Human. London: Palgrave.

Gilroy, Paul. 1993. The Black Atlantic: Modernity and Double Consciousness. London: Verso.

Giraud, Eva H. 2019. What Comes After Entanglement? Activism, Anthropocentrism, and an Ethics of Exclusion. Durham: Duke University Press.

Halberstam, Jack, and Ira Livingston. 1995. Posthuman Bodies. Bloomington: Indiana University Press.

Haraway, Donna J. 1991. Simians, Cyborgs, and Women: The Reinvention of Nature. New York: Routledge.

- - 2016. Staying with the Trouble: Making Kin in the Chthulucene. Durham: Duke University Press. Helmreich, Stefan. 2008. "Species of Biocapital." Science as Culture 17 (4): 463-78. 
Levin, Lisa A., and Nadine Le Brise. 2015. "The Deep Ocean Under Climate Change." Science 350 (6262): 766-68. https://doi.org/10.1126/science.aad0126.

Neimanis, Astrida. 2017. Bodies of Water: Posthuman Feminist Phenomenology. London: Bloomsbury.

Neimanis, Astrida, Cecilia Åsberg, and Johan Hedrén. 2015. "Four Problems, Four Directions for Environmental Humanities: Toward Critical Posthumanities for the Anthropocene." Ethics \& the Environment 20 (1): 67-97.

Neira, Maria, and Veerabhadran Ramanathan. 2020. "Climate Change, Air Pollution, and the Environment: The Health Argument." In Health of People, Health of Planet and Our Responsibility, edited by Wael K. Al-Delaimy, Veerabhadran Ramanathan, and Marcelo Sánchez Sorondo, 93-103. New York: Springer.

Nixon, Rob. 2013. Slow Violence and the Environmentalism of the Poor. Cambridge: Harvard University Press.

Oppermann, Serpil. 2019. "Storied Seas and Living Metaphors in the Blue Humanities." Configurations 27, no. 4 (Fall): 443-61.

Oreskes, Naomi. 2014. "Scaling up Our Vision." Isis: A Journal of the History of Science Society 105: 379 -91 .

Plumwood, Val. 1993. Feminism and the Mastery of Nature. London: Routledge.

Povinelli, Elizabeth. 2014. "Geontologies of the Otherwise: Theorizing the Contemporary." Cultural Anthropology, Last modified January 13, 2014.

https:/culanth.org/fieldsights/geontologies-of-the-otherwise.

Radomska, Marietta, 2018. "Promises of Non/Living Monsters and Uncontainable Life." Somatechnics 8 (2): 215-31.

Rich, Adrienne. (1984) 1987. "Notes toward a Politics of Location." In Blood, Bread and Poetry: Selected Prose 1979-1985, edited by Adrienne Rich, 210-31. London: Virago Press.

Ripple, William J., Christopher Wolf, Thomas M. Newsome, Mauro Galetti, Mohammed Alamgir, Eileen Crist, Mahmoud I. Mahmoud, and William F. Laurance. 2017. "World Scientists' Warning to Humanity: A Second Notice." BioScience 67, no. 12 (December): 1026-28. https://doi.org/10.1093/biosci/bixl25.

Rose, Deborah B. 2012. "Multispecies Knots of Ethical Time.” Environmental Philosophy 9 (1): 12740.

-__. 2015. "The Ecological Humanities." In Manifesto for Living in the Anthropocene, edited by Katherine Gibson, Deborah B. Rose, and Ruth Fincher, 1-7. New York: Punctum Books.

Rose, Deborah B., Thom van Dooren, Matthew Chrulew, Stuart Cooke, Matthew Kearnes, and Emily O'Gorman. 2012. "Thinking Through the Environment, Unsettling the Humanities." Environmental Humanities 1 (1): 1-5.

Roy, Arundhati. 2020. "The Pandemic is a Portal." Financial Times, April 3, 2020.

Schiermeier, Quirin. 2003. “Fish Farms' Threat to Salmon Stocks Exposed.” Nature 425: 753. https://doi.org/10.1038/425753a.

Steinberg, Philip, and Kimberley Peters. 2015. Wet Ontologies, Fluid Spaces: Giving Depth to Volume through Oceanic Thinking." Environment and Planning D: Society and Space 33 (2): $247-$ 64.

Tsing, Anna. 2015. The Mushroom at the End of the World: On the Possibility of Life in Capitalist Ruins. Princeton and Oxford: Princeton University Press.

Wolfe, Cary. 2003. Zoontologies: The Question of the Animal. Minneapolis: University of Minnesota Press. 
A Sea Change

Yusoff, Kathryn. 2019. A Billion Black Anthropocenes, or None. Minneapolis: Minnesota University Press. 